\title{
Frequency distribution of HCV genotypes among chronic hepatitis $C$ patients of Khyber Pakhtunkhwa
}

\author{
Sajid Ali $^{1}$, ljaz Ali ${ }^{2}$, Sadiq Azam ${ }^{1}$ and Bashir Ahmad ${ }^{1 *}$
}

\begin{abstract}
Background: Hepatitis C Virus (HCV) genotypes frequency is important for the predication of response to therapy and duration of treatment. Despite variable response rates experienced in the case of Interferon (IFN) -based therapies, there was scarcity of data on HCV genotypes frequency in Khyber Pakhtunkhwa (KPK).

Study Design: A total of 200 blood samples were collected from chronic HCV patients prior to the initiation of anti-viral therapy. The study population included patients from 6 districts of KPK. Active HCV infection was confirmed in case of all the patients by real time PCR. HCV genotypes were determined in each case by Typespecific PCR.

Results: The analysis revealed that out of 200 PCR positive samples; 78 (39\%) were 2a, 62 (31\%) were 3a, 16 (8\%) were $3 b, 34(17 \%)$ were untypable while $1 a, 2 b$ and $1 b$ were $3(1.5 \%), 2(1 \%)$ and $5(2.5 \%)$, respectively.

Conclusion: Genotype determination is not carried out prior to therapy in KPK. Although, the abundantly prevalent types (2a and 3a) of HCV in KPK are susceptible to combination therapy, yet resistance experienced in some of the chronic HCV patients may partly be attributed to the prevalence of less prevalent resistant genotypes (1a, 1b) of HCV among the population.
\end{abstract}

Keywords: Hepatitis C Virus Interferon, complementary DNA, Real-time PCR, Type specific PCR

\section{Background}

Chronic HCV infection frequently progresses to liver cirrhosis and is associated with an elevated risk for development of hepatocellular carcinoma [1-3]. Though symptoms may be mild for decades, $20 \%$ of persistently infected individuals may eventually develop severe liver disease including cirrhosis and liver cancer [1]. To date at least six major genotypes of HCV, each having multiple subtypes, have been identified worldwide [2]. The various $\mathrm{HCV}$ genotypes are important with respect to epidemiology, vaccine development and clinical management of chronic HCV infection [3]. HCV genotype has also been linked with sustained virological response [4]. Some studies have reported that patients with type 2 and type $3 \mathrm{HCV}$ infections are more likely to have a

\footnotetext{
* Correspondence: bashirdr2001@yahoo.com

${ }^{1}$ Centre for Biotechnology and Microbiology, University of Peshawar,

Peshawar, Khyber Pakhtunkhwa, Pakistan Full list of author information is available at the end of the article
}

sustained response to therapy than patients with type 1 $\mathrm{HCV}$ infections [5]. Sustained virological response to combination therapy in patients infected with $\mathrm{HCV}-2 / 3$ and $\mathrm{HCV}-1$ genotypes are $65 \%$ and $30 \%$, respectively $[6,7]$. Therefore, HCV genotype should be determined prior to therapy.

HCV genotypes 1, 2 and 3 appear to have a worldwide distribution while subtypes $1 \mathrm{a}$ and $1 \mathrm{~b}$ are the most common genotypes in the United States [4] and Europe [8-10]. The most abundant subtype in Japan is subtype $1 \mathrm{~b}$ [11]. HCV subtypes $2 \mathrm{a}$ and $2 \mathrm{~b}$ are relatively common in North America, Europe and Japan and subtype $2 \mathrm{c}$ is found commonly in northern Italy. HCV genotype 4 appears to be prevalent in North Africa and the Middle East $[12,13]$ and genotypes 5 and 6 are found in South Africa and Hong Kong, respectively [14,15]. HCV genotypes 7, 8 and 9 have been identified only in Vietnamese patients [16] and genotypes 10 and 11 have been identified in patients from Indonesia [17]. There is
C Biomed Central 
disagreement about the number of genotypes into which HCV isolates should be classified and genotypes 7 through 11 should are regarded by some researchers as variants of the same group and classified as a single genotype, type $6[18,19]$.

In Pakistan, few studies have been conducted in order to figure out the geographical distribution of various HCV genotypes [13,20,21]. In Khyber Pakhtunkhwa, the prevalence of various $\mathrm{HCV}$ genotypes is unknown. As $\mathrm{HCV}$ genotypes have earlier been implicated in response to therapy [4], therefore it was of prime importance to investigate the frequency distribution of HCV genotypes in Khyber Pakhtunkhwa province of Pakistan where genotype determination prior to therapy is not common practice.

\section{Methodology}

Samples were collected from chronically infected patients with HCV. None of the patients selected for the study had started with anti-viral therapy. All the patients duly signed a proforma containing their demographics, previous history of viral infection etc. Serum was isolated and extraction of RNA was carried out with spin column based method (Roboscreen extraction kit) according to the manufacturer's instructions. HCV-RNA was amplified using reagents and equipment from the Cepheid (Cepheid, USA).

$\mathrm{HCV}$ genotyping was performed according to the procedure of Ohno et al., [22]. Briefly, HCV-RNA was reverse transcribed to cDNA using $100 \mathrm{U}$ of $\mathrm{M}-\mathrm{MLV}$ reverse transcriptase at $37^{\circ} \mathrm{C}$ for 50 minutes. Two $\mu \mathrm{l}$ of synthesized cDNA was used for subsequent PCR amplification of 470-bp region from $\mathrm{HCV} 5$ ' noncoding region plus core region by first round PCR. The second round nested PCR was performed using Type-specific primers for genotypes 1a, 1b, 1c, 3a, 3c, 4, 2a, 2c, 3b, 5a and $6 \mathrm{a}$. The final PCR product was electrophorased on a $2 \%$ agarose gel to separate type-specific amplified fragments. A 100-bp DNA ladder (Invitrogen, Corp., California, USA) was run in each gel as DNA size marker and the HCV genotype for each sample was determined by identifying the HCV genotype-specific PCR band.
Table 1 Prevalent HCV genotypes among the Chronic HCV infected patients of Khyber Pakhtunkhwa.

\begin{tabular}{|c|c|c|c|c|c|}
\hline $\begin{array}{r}\text { S. } \\
\text { No }\end{array}$ & Genotypes & Subtypes & $\begin{array}{r}\text { No of } \\
\text { isolates }\end{array}$ & $\begin{array}{r}\% \\
\text { Frequency }\end{array}$ & $\begin{array}{l}\text { T. No of } \\
\text { isolates }\end{array}$ \\
\hline \multirow[t]{2}{*}{1} & 2 & $2 \mathrm{a}$ & 78 & $39 \%$ & 80 \\
\hline & & $2 b$ & 2 & $1 \%$ & \\
\hline \multirow[t]{2}{*}{2} & 3 & $3 a$ & 62 & $31 \%$ & 78 \\
\hline & & $3 b$ & 16 & $8 \%$ & \\
\hline \multirow[t]{2}{*}{3} & 1 & $1 a$ & 3 & $1.5 \%$ & 8 \\
\hline & & $1 b$ & 5 & $2.5 \%$ & \\
\hline \multirow[t]{2}{*}{4} & Untypable & Untypable & 34 & $17 \%$ & 34 \\
\hline & & & Total & 100 & 200 \\
\hline
\end{tabular}

\section{Results}

$\mathrm{HCV}$ genotype analysis in chronic $\mathrm{HCV}$ patients (age 15-60 years) of Khyber Pakhtunkhwa revealed that the most abundant genotypes/subtypes among the patients analyzed were 2a followed by subtype 3 a (Table 1 ). Other common genotypes included the untypable type of the virus and genotype $3 \mathrm{~b}$. Comparatively less common genotypes were $1 \mathrm{~b}, 1 \mathrm{a}$ and $2 \mathrm{~b}$ (Table 1 ). Major risk factors associated with $\mathrm{HCV}$ infection were blood transfusion and dental surgery followed by major surgery (Table 2). The patient's history indicated that comparatively more patients had a history of blood transfusion in Peshawar and Mardan districts while a history of dental surgery practices was common in less developed district Bunir. Moreover, district Bunir and Peshawar had more cases of a positive family history of HCV infection as well. In the studied individuals, there were no coinfections. It was also noted that the overall prevalence of chronic HCV was more in male as compared to female (Table 2).

\section{Discussion}

HCV prevalence is alarmingly high in Pakistan and due to unsatisfactory health care conditions, the infection is spreading at a rapid pace [20]. In Khyber Pakhtunkhwa, where the health care facilities are poorly equipped with essentials for screening and sterilization, HCV has become an economic burden over a population with

Table 2 Demographics of Chronic HCV infected patients.

\begin{tabular}{|c|c|c|c|c|c|c|c|}
\hline District & Age & M/F Ratio & $\begin{array}{l}\text { Family History } \\
\text { of HCV infection }\end{array}$ & Co-infection & Major surgery & Blood transfusion & Dental surgery \\
\hline Bunir & $22-56$ & $11 / 5$ & $5 \%$ & Nil & $2 \%$ & $5 \%$ & $9 \%$ \\
\hline Swabi & $18-53$ & $13 / 8$ & $3 \%$ & $=$ & $4 \%$ & $6 \%$ & $7 \%$ \\
\hline Dir & $16-58$ & $18 / 12$ & $2 \%$ & $=$ & $3 \%$ & $5 \%$ & $8 \%$ \\
\hline Kohat & $20-45$ & $16 / 9$ & $2 \%$ & $=$ & $3 \%$ & $4 \%$ & $6 \%$ \\
\hline Mardan & $19-56$ & $29 / 18$ & $3 \%$ & $=$ & $4 \%$ & $8 \%$ & $7 \%$ \\
\hline Peshawar & $15-60$ & $41 / 23$ & $4 \%$ & $=$ & $4 \%$ & $9 \%$ & $5 \%$ \\
\hline
\end{tabular}


considerable number of people living below the poverty line.

$\mathrm{HCV}$ genotype determination facilitates therapeutic decisions and strategies $[23,24]$ and it has been reported that pathogenesis of the disease or response to therapy may vary according to the type of the virus $[9,25]$. Genotype determination is not carried out prior to treatment in Khyber Pakhtunkhwa and the treatment strategies are solely based on qualitative or quantitative viral detection. Reasons for variable response rates in the case of different patients for both combination therapy and Pegylated IFN could therefore not properly be sorted out. We attempted to figure out HCV genotypes prevalent among the population of Khyber Pakhtunkhwa so as to create awareness among the practitioners about the importance of the HCV genotype and find a preliminary answer to the resistance phenomenon experienced here.

Our study indicated that $\mathrm{HCV}$ genotype $2 \mathrm{a}$ is the most abundant followed by $3 \mathrm{a}$ and $2 \mathrm{~b}$ (Table 1 ). The distribution of type 2 and 3 is thought to be worldwide [4] including Pakistan [10]. It has earlier been reported that HCV 2a and 3a are most susceptible to combination therapy [5] and good response rates in Khyber Pakhtunkhwa may partly be attributed to the most abundant types of HCV prevalent here. Other types of the virus including type $1 \mathrm{a}, 1 \mathrm{~b}$ and $2 \mathrm{~b}$ are less prevalent among the population (Table 1). Genotype $1 \mathrm{a}$ and $1 \mathrm{~b}$ are prevalent in the USA [4], Europe [8,9] and Japan [11]. These genotypes are comparatively less responsive to combination therapy [5] and the response rates in the case of Pegylated IFN have been reported to vary from 50-70\% [26]. In Khyber Pakhtunkhwa, it is a common practice to put the non-responders on prolonged combination therapy or Pegasys. Resistance in some patients may be attributed to these less prevalent genotypes among the population.

HCV genotypes among a considerable number of chronic HCV patients (17\%) could not be determined by the assay used in this study. Untypeable genotypes have earlier been reported by other studies conducted in Pakistan [23]. Sequencing of the untypeable genotypes is needed not only for academic reasons but also for future treatment directions.

This study concludes that the most abundant types of $\mathrm{HCV}$ among chronic HCV patients of Khyber Pakhtunkhwa province of Pakistan are HCV type 2a, 3a and $3 b$. Although these abundant types are responsive to combination therapy and Pegasys, yet proper diagnostic and treatment strategies should be adopted in order to minimize the economic burden on the population and to prevent people from an extra stress of undergoing successive therapies.

\section{Author details}

${ }^{1}$ Centre for Biotechnology and Microbiology, University of Peshawar, Peshawar, Khyber Pakhtunkhwa, Pakistan. ${ }^{2}$ Institute of Biotechnology and Genetic Engineering, Agricultural University, Peshawar, Khyber Pakhtunkhwa, Pakistan.

\section{Authors' contributions}

SA (research scholar) carried out sampling and experimental work, BA supervised the research work conducted by SA and designed the experimental work and manuscript preparation with the help of IA (Cosupervisor). SA helped in manuscript reviewing and corrections prepared by research scholar. The final manuscript is approved by all of the authors after reviewing it critically.

\section{Competing interests}

The authors declare that they have no competing interests.

Received: 5 February 2011 Accepted: 26 April 2011 Published: 26 April 2011

\section{References}

1. MJ Alter, HS Margolis, K Krawczynski, FN Judson, A Mares, WJ Alexander, YP Hu, JK Miller, MA Gerber, RE Sampliner, The natural history of communityacquired hepatitis $C$ in the United States. The sentinel counties chronic non-a, non-b hepatitis study team. The New England journal of medicine. 327, 1899-1905 (1992). doi:10.1056/NEJM199212313272702

2. AU Neumann, NP Lam, H Dahari, DR Gretch, TE Wiley, TJ Layden, AS Perelson, Hepatitis C viral dynamics in vivo and the antiviral efficacy of interferon-alpha therapy. Science New York NY. 282, 103-107 (1998)

3. IT Saito, A Miyamura, H Ohbayashi, T Harada, S Katayama, Y Kikuchi, S Watanabe, M Koi, Y Ohta, Hepatitis C Virus infection is associated with the development of hepatocellular carcinoma. Proceedings of the National Academy of Sciences of the United States of America. 87, 6547-6549 (1990). doi:10.1073/pnas.87.17.6547

4. NN Zein, J Rakela, EL Krawitt, KR Reddy, T Tominaga, DH Persing, Hepatitis $C$ virus genotypes in the United States: epidemiology, pathogenicity, and response to interferon therapy. Ann Intern Med. 125, 634-639 (1996)

5. D Dusheiko GH. Schmilovitz, F Brown, P McOmish, L Yap, P Simmonds, Hepatitis $C$ virus genotypes. An investigation of type-specific differences in geographic origin and disease. Hepatology. 19, 13-18 (1996)

6. JG MCHutchison, SC Gordon, ER Schiff, ML Shiffman, WM Lee, VK Rustgi, ZD Goodman, Interferon alfa-2b alone or in combination with ribavirin as initial treatment for chronic hepatitis C. Hepatitis Interventional Therapy Group. N Engl J Med. 339, 1485-1492 (1998). doi:10.1056/NEJM199811193392101

7. TP Poynard, SS Marcellin, C Lee, GS Niederau, G Minuk, V Ideo, Bain, IL Yap, BC Dow, EAC Follett, C Seed, AJ Keller, TJ Cobain, T Krusius, E Kolho, R Naukkarinen, C Lin, C Lai, S Leong, GA Medgyesi, M Heéjjas, H Kiyokawa, K Fukada, T Cuypers, AA Saeed, AM Al-Rasheed, M Lin, P Simmonds, Geographic distribution of hepatitis C virus genotypes in blood donors: an international collaborative survey. J Clin Microbiol. 32, 884-92 (1994)

9. GJ Dusheiko, H Thomas, Ribavirin treatment for patients with chronic hepatitis C: results of a placebo-controlled study. J Hepatol. 25(Suppl 5):591-598 (1994)

10. JB Nousbaum, S Pol, B Nalpas, P Landais, P Berthelot, C Brechot, The Collaborative Study Group: Hepatitis C virus type 1b (II) infection in France and Italy. Ann Intern Med. 122, 161-168 (1995)

11. NS Takada, S Takase, A Takada, Differences in the hepatitis C virus genotypes in different countries. J Hepatol. 17, 277-283 (1993). doi:10.1016/ S0168-8278(05)80205-3

12. AS Abdulkarim, NN Zein, JJ Germer, CP Kolbert, L Kabbani, KL Krajnik, A Hola, MN Agha, M Tourogman, DH Persing, Hepatitis C virus genotypes and hepatitis $G$ virus in hemodialysis patients from Syria: identification of two novel hepatitis C virus subtypes. Am J Trop Med Hyg. 59, 571-576 (1998)

13. RW Chamberlain, N Adams, AA Saeed, P Simmonds, RM Elliot, Complete nucleotide sequence of a type 4 hepatitis $C$ virus variant, the predominantgenotype in the Middle East. J Gen Virol. 78, 1341-1347 (1994)

14. P Simmonds, EC Holmes, TA Cha, SW Chan, F McOmish, B Irvine, E Beall, PL Yap, J Kolberg, MS Urdea, Classification of hepatitis C virus into six major genotypes and a series of subtypes by phylogenetic analysis of the NS-5 region. J Gen Virol. 74, 2391-9 (1993). doi:10.1099/0022-1317-74-11-2391 
15. TA Cha, J Kolberg, B Irvine, M Stempien, E Beall, M Yano, QL Choo, M Houghton, G Kuo, JH Han, MS Urdea, Use of a signature nucleotide sequence of hepatitis $C$ virus for detection of viral RNA in human serum and plasma. J Clin Microbiol. 29, 2528-2534 (1992)

16. HS Tokita, M Shrestha, H Okamoto, S Sakamoto, M Horikita, H lizuka, S Shrestha, Y Miyakawa, M Mayumi, Hepatitis C virus variants from Nepal with novel genotypes and their classification into the third major group. J Gen Virol. 75, 931-936 (1994). doi:10.1099/0022-1317-75-4-931

17. HH Tokita, H Okamoto, H lizuka, F Kishimoto, L Tsuda, A Lesmana, Y Miyakawa, M Mayumi, Hepatitis C virus variants from Jakarta, Indonesia classifiable into novel genotypes in the second (2e and 2f), tenth (10a) and eleventh (11a) genetic groups. J Gen Virol. 77, 293-301 (1996). doi:10.1099/ 0022-1317-77-2-293

18. X DeLamballerie, RN Charrel, H Attoui, P DeMicco, Classification of hepatitis $C$ virus variants in six major types based on analysis of the envelope 1 and nonstructural 5B genome regions and complete polyprotein sequences. J Gen Virol. 78, 45-51 (1997)

19. HH Tokita, H Okamoto, J lizuka, F Kishimoto, Y Tsuda, M Mayumi, The entire nucleotide sequences of three hepatitis $C$ virus isolates in genetic groups 79 and comparison with those in the other eight genetic groups. J Gen Virol. 79, 1847-1857 (1998)

20. HA Shah, WS Jafri, I Malik, L Prescott, P Simmonds, Hepatitis C virus (HCV) genotypes and chronic liver disease in Pakistan. J Gastroenterol Hepatol. 12 758-761 (1997). doi:10.1111/j.1440-1746.1997.tb00366.x

21. M Idrees, Common genotypes of hepatitis $C$ virus present in Pakistan. Pak J Med Res. 40(Suppl 2):46-49 (2001)

22. T Ohno, M Mizokami, R Wu, M Saleh, K Ohba, E Orito, M Mukaide, R Williams, J Lau, New hepatitis $C$ virus genotyping system that allows for identification of HCV genotypes 1a, 1b, 2a, 2b, 3a, 3b, 4, 5a, and 6a. J Clin Microbiol. 35, 201-207 (1997)

23. T Poynard, P Bedossa, M Chevallier, P Matturin, C Lemonnier, C Trepo, P Couzigou, JL Payen, M Sajus, JM Costa, M Vidaud, JC Chaput, the Multicenter Study Group, A comparison of three Interferon alpha 2b regimens for long terms treatment of chronic non $A$, non $B$ hepatitis. $N$ Engl J Med. 332, 1457-62 (1995). doi:10.1056/NEJM199506013322201

24. GL Davis, R Esteban-Mur, V Rustgi, J Hoefs, SC Gordon, C Trepo, ML Shiffman, S Zeuzem, A Craxì, MH Ling, J Alvrecht, Interferon alpha-2b alone or in combination with ribavirin for the treatment of relapse of chronic hepatitis C. N Engl J Med. 339, 1493-1499 (1998). doi:10.1056/ NEJM199811193392102

25. JG McHutchison, T Poynard, GL Davis, R Esteban-Mur, J Harvey, M Ling, S Cort, JJ Fraud, J Albrecht, J Dienstag, Evaluation of hepatic HCV RNA before and after treatment with interferon alfa $2 \mathrm{~b}$ or combined with ribavirin in chronic hepatitis. Hepatology. 30(Suppl 2):363A (1990)

26. SJ Hadziyannis, H Sette, J Morgan, TR Balan, V Diago, M Marcellin, P Ramadori, G Bodenheimer, HJ Bernstein, D Rizzetto, S Pockros, PJA Lin, AM Ackrill, Peginterferon-alpha2a and ribavirin combination therapy in chronic hepatitis $\mathrm{C}$. a randomized study of treatment duration and ribavirin dose. Ann Intern Med. 140, 346-55 (2004)

doi:10.1186/1743-422X-8-193

Cite this article as: Ali et al:. Frequency distribution of HCV genotypes among chronic hepatitis C patients of Khyber Pakhtunkhwa. Virology Journal 2011 8:193.

\section{Submit your next manuscript to BioMed Central and take full advantage of:}

- Convenient online submission

- Thorough peer review

- No space constraints or color figure charges

- Immediate publication on acceptance

- Inclusion in PubMed, CAS, Scopus and Google Scholar

- Research which is freely available for redistribution

Submit your manuscript at www.biomedcentral.com/submit 